\title{
Responding to Students' Errors in Online Practical Translation Classes
}

\author{
Sabir Hasan Rasul \\ Department of English, College of Languages, University of Human Development, Sulaimani, Kurdistan Region - F.R. Iraq
}

\begin{abstract}
In practical translation classes it is inevitable that students make translation errors. Making errors is in fact a characteristic of translation training process, and the role of the teacher is to respond and offer timely and appropriate correction/feedback so that students are able to differentiate between correct and erroneous translations. Training students to develop the ability to produce correct and accurate translation is part and parcel of any practical translation classes. This paper, which has a pedagogical nature, investigates the treatment of students' errors in online practical translation classes. It extends the area of 'responding to errors' to translation studies, on the one hand, and to online classes, on the other hand. Following Thompson's (2007) model of responding to errors, the paper attempts to find out when and how teachers respond to translation errors made by students in online English-Kurdish practical translation classes. The results show that the teachers respond to the vast majority of translation errors occurred in the course of the online classes. In terms of time, the teachers never interrupted students instantly but waited until the end of translation units or utterances and then responded to the errors. In terms of the method of responding, the results revealed that the teachers mostly focused on meaning and used various techniques of error responding, including students' involvement and offering their own corrections (with or without feedback). These results, coupled with critical comments provided, are hoped to offer useful insights to would-be translation teachers and trainers to better understand how and when to respond to students' errors in online practical translation classes.
\end{abstract}

Index Terms - translation errors, responding to students' errors, online practical translation classes, English-Kurdish translation

\section{INTRODUCTION}

Responding to students' errors in the field of language learning has been broadly explored (cf. Allwright and Bailey 1991; Harmer 2001; Amara 2015). Exploring students' errors in translation classes, however, has remained largely underresearched. Numerous translation researchers investigated translation errors or mistranslations (cf. Pym 1992; Hansen 2010; Popovic and Ney 2011; Ghasemi and Hasemian 2016; Rasul 2016; Carl and Báez 2019), however none of them touched upon the area of error responding in translation classrooms.
This paper extends the study of 'error responding' to online practical translation classes and specifically aims to answer the following questions:

1) When and how do teachers respond to students' translation errors in online practical translation classes between English and Kurdish?

2) To what extent can the teachers' responses to students' translation errors be deemed effective?

Following an adapted version of Thompson's (2007) model of responding to errors, the paper attempts to identify the time of responding to student translation errors and the approach of responding taken by the teachers.

\section{A. Types and Definitions of Errors}

Julian Edge (1989) distinguishes three categories of mistakes in the process of language learning, as follows:

(1) Slips: mistakes which students can correct themselves once the mistakes have been pointed out to them;

(2) Errors: mistakes which students cannot correct themselves - and which therefore need explanation; and,

(3) Attempts: when a student tries to say something but does not yet know the correct way of expressing it.

(Edge 1989, in Harmer 2001: 99)

Harmer (2001: 99) believes that "it is the category of errors that most concerns teachers". By extension, it is also the category of errors that is most relevant in translation training classes. However, translation scholars and/or trainers do not agree on a specific definition and classification of 'translation errors'. For example, terms such as mistranslation, incorrect translation, translation mistakes and translation errors are used in the literature, and classifications such as absolute and relative errors (Gouadec 1989) and binary and non-binary errors (Pym 1992) are proposed. For the purpose of this study, we adopt Anthony Pym's (1992) practical classification, who distinguishes between binary and non-binary errors:

(1) Binary errors: they refer to errors that are considered as incorrect translation. They are always wrong in all circumstances. A binary error is a major translation error "that seriously impedes the main message" transferred

Journal of University of Human Development

Volume 7 No. 3(2021); DOI: 10.21928/juhd.v7n3y2021.pp82-91

Regular research paper: Received 25 July 2021; Accepted 19 August 2021; Published 22 August 2021

Corresponding author's e-mail: sabir.rasul@uhd.edu.iq

Copyright @2021 Sabir Hasan Rasul. This is an open access article distributed under the Creative Commons Attribution License

(CC BY-NC-ND 4.0). 
from the source language (SL) to the target language (TL) (Williams 2004: 6). Consider translating داكثانى [ئابوورى [economic incline] as economic downfall, in Example 11 below, which is a binary error.

(2) Non-binary errors: they refer to errors that are not absolutely wrong, but they can be replaced by more appropriate alternatives and translation options. They are wrong to some extent and/or in some circumstances. Consider translating embezzlement as كَندّلى [corruption], which is inaccurate because not all types of corruption are embezzlements. A more accurate option would be ئيختيلاس - a loanword from Arabic which is commonly used in the Kurdish legal language.

\section{B. Online Practical Translation Classes}

The Covid-19 pandemic has affected many aspects of life, especially social, commercial and educational. This has led many educational institutions worldwide to adopt online teaching fully or partially. Likewise, the Kurdistan Regional Government's Ministry of Higher Education and Scientific Research proposed a blended method of teaching, in which lessons are delivered partly on campus and partly online. The online classes are meant to be live classes (using online platforms such as Zoom) to allow student interaction and are recorded to be available for students' later use in the form of video clips.

Online translation courses are said to "have peculiar epistemological and pedagogical characteristics which differ from those available in conventional teaching settings" (Ismail et al. 2019: 176). When teaching online, teachers usually do not have access to a whiteboard to make notes and explanations. Typing on computer and sharing screen with students is a feasible solution, however it is both distracting and timeconsuming. In the chosen lessons, the teachers share the textual material (the source text to be translated) with students on screen and depend on oral communication to do the translation practice. Therefore, both students' errors and teacher's responses are oral in nature.

\section{MATERIAL AND METHODOLOGY}

The material used in the research consists of three recorded video clips of online practical translation classes between English and Kurdish at the undergraduate level. Each video is approximately 40 minutes in length. Two video clips are produced in the English Department of the University of Human Development, and the other one is produced at the Translation Department of Cihan University. Consent is taken to use the video clips for the purpose of this study. Details of the videos are given below:

\section{Lesson 1:}

Topic: Translation of legal texts (English into Kurdish)

Course: Translation Practice II (Department of English, University of Human Development).

Level: Semester 7

\section{Lesson 2:}

Topic: Translation of economics texts (Kurdish into English)
Course: Translation Practice II (Department of English, University of Human Development).

Level: Semester 7

\section{Lesson 3:}

Topic: Translation of general texts (English into Kurdish) Course: Translation from English into Kurdish IV (Department of Translation, Cihan University).

\section{Level: Semester 6}

As for the methodology, the study is based on 'class observation'. The process involves watching the video clips of the lessons thoroughly, detecting and noting down errors made by students, and checking whether the teacher responds to the errors. If so, noting down when and how the teachers respond to each error. All the errors detected, along with teacher responses, are documented in a table (see Appendix 1). The table contains the source text utterance, followed by student's translation (in which the error occurs), followed by the teacher's correction/response, with the area of question being underlined, as demonstrated below.

\begin{tabular}{|c|c|c|}
\hline ST (Kurdish) & $\begin{array}{l}\text { TT with error } \\
\text { (English) }\end{array}$ & $\begin{array}{c}\text { Teacher's } \\
\text { correction/respons } \\
\text { e }\end{array}$ \\
\hline 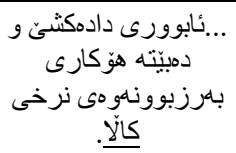 & $\begin{array}{l}\text {...the economy will } \\
\text { decline which results } \\
\text { in a rise in the price of } \\
\text { facilities. }\end{array}$ & $\begin{array}{l}\text {...the economy will } \\
\text { decline which } \\
\text { results in a rise in } \\
\text { the price of goods. }\end{array}$ \\
\hline
\end{tabular}

The errors are classified into binary errors and non-binary translation errors based on Pym's (1992) translation error categorization. The example above is designated as an instance of binary translation error, because the two terms كالע [goods] and facilities are essentially different.

To systematically classify the types of student errors and teacher responses, a specific form is used (see Appendices 2, 3 and 4). The form is adapted from Geoff Thompson's (2007) model of 'Responding to Errors' used in Classroom Observation course, MA in TESOL, School of English, University of Liverpool. The model is essentially devised to investigate oral errors in language learning classes. In this study, the model is adapted to oral errors in online practical translation classes. The first part of the form focuses on the time and method of responding to student errors. As far as the time is concerned, teachers have three options:

(1) Interrupt students: it is normally discouraging to interrupt students while they answer a question or make a contribution in class. "Interrupting the learner in midsentence... could eventually inhibit his/her willingness to speak in class at all" (Allwright and Bailey 1991: 103).

(2) Delay to end of student's utterance: this is a more effective way of responding to student errors, which allows the leaner to contribute to the lesson confidently without being interrupted.

(3) Delay to end of activity: this usually happens in the case of pairwork or groupwork activities. When the teacher hears an error, he/she can wait until the end of the activity and 
then provide necessary correction/feedback. "With regard to fluency activities, the usual advice is to delay feedback until the end of the activity so as to avoid interrupting the student's flow of speech" (Kostić-Bobanović 2007: 379).

Regarding the method of responding to errors, the model proposes six possible techniques, as follows:

(1) Mirror with correction: this is an indirect way of correcting student errors; after a student makes an error, the teacher repeats the utterance in a correct form.

(2) Get student to correct: this is what Thornbury terms 'finger-coding', which involves repeating the utterance and stop in the place where the error has been made and give the student the chance of self-correction (Thornbury 1999: 117).

(3) Asking other student(s) to correct: when an error occurs and the individual student cannot correct himself/herself, the teacher can ask other students to help out and answer correctly. This can be both advantageous and disadvantageous. On the one hand, this leads to more contribution and coordination among students. On the other hand, there are always some students in the class who may not feel well to receive correction from classmates as this may create a sense of inferiority. Such a risk can be mitigated if the teacher establishes a tone of cooperation and coordination in the class.

(4) Offer correction with feedback: offering direct correction by the teacher is a simple way of responding to errors but not an effective one. However, this can be enhanced when followed by necessary feedback to draw students' attention to the nature of the error.

(5) Offer correction without feedback: this is arguably the least effective way of correcting student errors. Since in this technique student's attention is not drawn, there is always the possibility that the student will repeat the same error.

(6) Ignore: This occurs when the teacher simply chooses not to respond to a student error. At the first glance, the idea of ignoring student errors in class seems to be a negative and dispreferred technique. It is, however, fully accepted for the teacher to ignore some errors depending on the purpose of the activity. For instance, in a communicative class where the content is of utmost importance, errors in grammar can be tolerated.

The second part of the model sheds light on the context in which an error is made and responded to, specifically highlighting whether the focus of the class is on the form or content. To adapt the model to translation classes, the criteria is modified to cover 'form' and 'meaning'. The 'form' is concerned with errors in linguistic and grammatical structures of language (which can be corrected by the teacher overtly or covertly), whereas 'meaning' is concerned with errors in the message (which can be accepted or rejected by the teacher).

\section{ANALYSIS AND DISCUSSION}

Although there are differences in error responding among the three chosen lessons, the study is more concerned with results as a whole, rather than results of individual lessons or teachers. Therefore, the results will be dealt with collectively in terms of the time and manner of teacher responding as well as the focus of teachers' correction/feedback.

\section{A. Time of Responding to Student Errors}

In total, 51 translation errors occurred in the data. In terms of time, the teachers responded to 43 translation errors at the end of utterances or translation units. The remaining translation errors ( 8 instances) are simply ignored by the teachers. That is, teachers have not interrupted students instantly, nor have they delayed the respond/feedback to the end of activity. The reason for this might be the fact that the teachers carried out the translation based on translation units, which could be a single word or an utterance. Moreover, no pairwork or groupwork activity is done to delay response to the end of activities. While teaching online, it is difficult to do pairwork or groupwork activities.

\section{B. Method of Responding to Student Errors}

As the results reveal, the teachers responded to the vast majority of errors made by students ( $84 \%$ ), using a variety of techniques as shown in Figure 1 below. The least frequent technique is 'mirroring with correction', whereas the most frequent is 'offering correction without feedback'. It is concerning that in one-third of occurrences students are corrected but not provided with feedback. Appropriate feedback can axiomatically contribute to more effective learning. It is also concerning that a considerable proportion of errors (16\%) are simply ignored by the teachers.

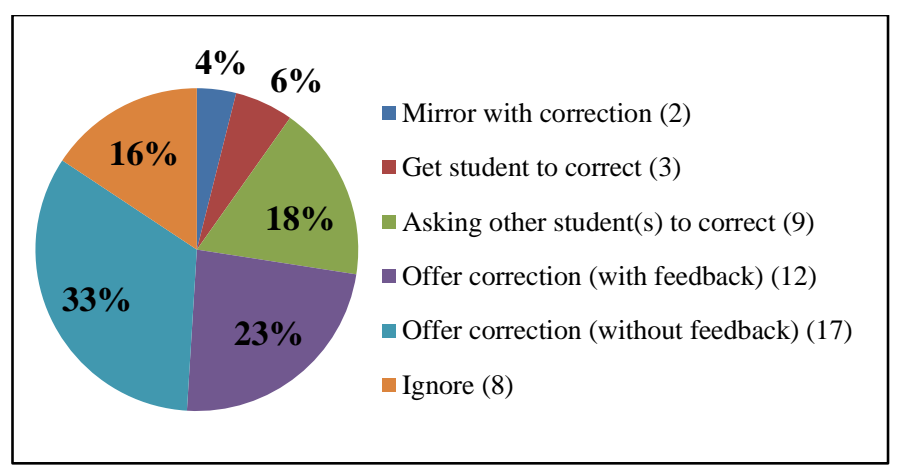

Fig. 1. Percentages of different techniques of error responding in the data

(1) Mirror with correction: only on two occasions, the teachers mirrored with correction. Consider the following example, in which the student mistakenly translated receipt as ليست [list], and the teacher repeated the translation in a correct form:

\section{Example 1:}

ST: Make sure that you get a receipt for the payment you make.

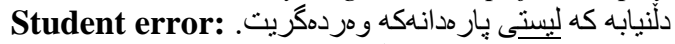

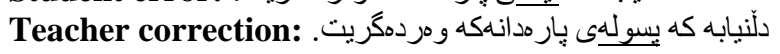


Likewise, when a student made a seemingly minor error translating their child as مندالّكانى [his children], in the example below, the teacher mirrored with correct translation. Moreover, the teacher explained that the text talks about $a$ child rather than children.

\section{Example 2:}

ST: ...he was trying to get custody of their child.

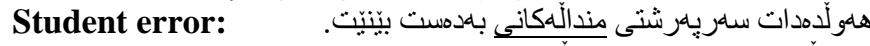

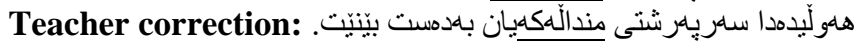

According to Newmark (1988: 85), it is sometimes acceptable to make a shift from singular to plural or vice versa (e.g. news > هلو اللّكان; the Kurds > كورد). The example above is taken from a legal document and a change from singular to plural in a legal context can potentially be confusing and misleading.

(2) Get student to correct: in this technique the teacher helps the student to correct himself or herself, usually by providing some clues. "Students learn more effectively if they are guided in such a way that they eventually correct themselves rather than if they are given the correct version of something straight away" (Gower et al. 1995: 165). There are only three instances in the data, where teachers get students to correct their own errors. Consider the example below, in which a student erroneously translated the idiomatic expression 'to remains prisoners of their own anger' by applying literal translation, which resulted in a binary translation error. The teacher got the student to correct herself by giving the clue that, based on the context, there is no 'prisoner' per se and expression is rather idiomatic which cannot be rendered literally.

\section{Example 3:}

ST: The first group remains prisoners of their own anger and bitterness.

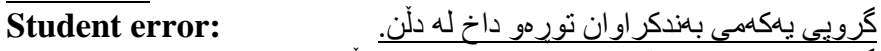

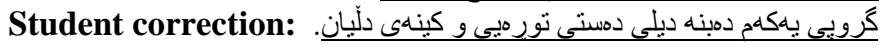

(3) Asking other student(s) to correct: This is a possible technique when a student makes an error and the teacher does not want to correct the error straightway. As long as the teacher has established a tone of mutual cooperation in class, he/she can ask other students to offer correction. Consider the following example, in which a student translated خانووبةره as accommodation, which is not quite accurate. The teacher asked other students for a more appropriate translation, and another student suggested real estate, which is a one-to-one counterpart of Kurdish خانووبهر.

\section{Example 4:}

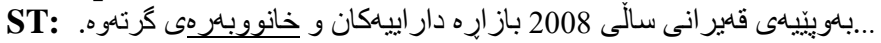
Student error: ... .because the 2008 crisis affected financial markets and accommodation.

Student correction: ...because the 2008 crisis affected financial markets and real estate.

Likewise, when a student mistakenly translated سندوقةكانى دلنيايى as security funds, the teacher sought correction from other students. Immediately a student volunteered and accurately translated the phrase as insurance funds, as demonstrated below:

\section{Example 5:}

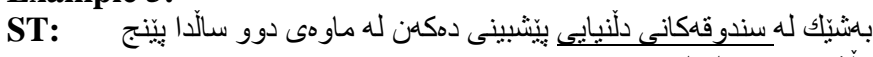

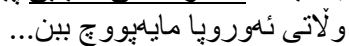

Student error: Some security funds predict that five European countries will go bankrupt within two years...

Student correction: Some insurance funds predict that five European countries will go bankrupt within two years...

(4) Offer correction with feedback: teacher correction can be more effective when feedback is offered and students' attention is drawn to the error in question. However, it is crucial that students are not interrupted in mid-sentence but allowed to complete the message they want to deliver. In nearly one-fourth of occurrences the teachers corrected students and offered feedback, as in the two examples below:

\section{Example 6:}

ST: The claimant must let the court know before the eviction is due to take place.

Student error:

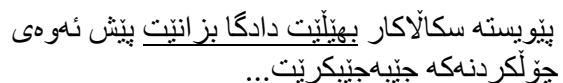

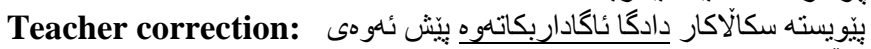

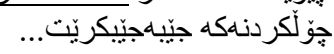

Here, the teacher not only offered correction, but also provided feedback, saying "do not use literal translation in this particular case, because 'to let... know' is an idiom, which means ئاكاداركردنهوه [to inform]". In fact, some idioms can be translated literally, which involves "the replacement of an SL idiom by a TL idiom which has roughly the same meaning and linguistic form" (Rasul 2018: 124). However, as Baker (2018: 71) states, "this kind of match can only occasionally be achieved". In the majority of cases, "the real danger comes in translating an idiom literally, since the result will usually be nonsense on the receptor language" (Larson 1998: 126).

\section{Example 7:}

ST: Spousal Abuse: physical, sexual, or psychological violence...

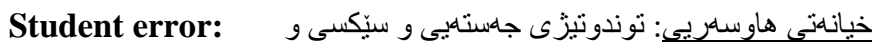

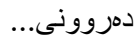

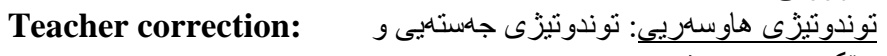

$$
\text { سنّكسى و دمروونى هارئ... }
$$

When the teachers asked students to translate the legal term spousal abuse in the example above, a student volunteered and translated it as خيانتى هاوسمريى [spousal infidelity], which is a binary translation error. The teacher rejected the translation and explained the meaning of each of the two words in a bid to offer his own translation, saying "No, abuse is a kind of violence and spousal refers to partners, i.e. husband and wife. Therefore, spousal abuse can be translated as توندوتيزى هاوسكريى [spousal violence]". Since Kurdish does not have a ready equivalent to the term abuse, it is normally translated by generalization as [violence]. 
(5) Offer correction without feedback: this is a quick and timesaving technique of responding to student errors, however it does not have a long-lasting effect. With 17 occurrences (33\%), offering correction without feedback is by far the most frequent technique implemented by the teachers. This might be ascribed to the inherent nature of online teaching, in which "feedback to students can be a lengthy and challenging process" (Lewis and Abdul-Hamid 2006: 91). Below are two instances in which the teachers offered correction without further elaboration:

\section{Example 8:}

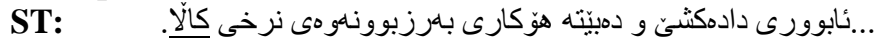
Student error: ...the economy will decline which results in a rise in the price of facilities.

Teacher correction: ...the economy will decline which results in a rise in the price of goods.

Here, the teacher could foster the correction by explaining the difference between facilities and goods - while the former refers to services or amenities, the latter refers to merchandise or possessions.

\section{Example 9:}

ST: Cybertheft: the act of using an online service... to steal someone else's property...

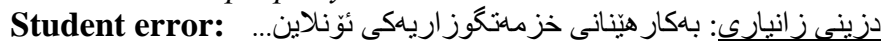

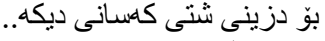

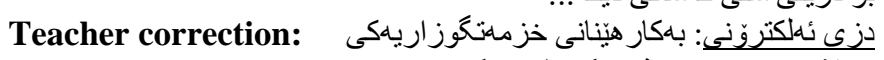

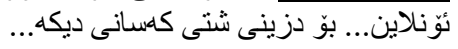

(6) Ignore: there are 8 occurrences of student errors (16\%) where the teachers simply chose not to respond to students' errors. The danger of ignoring students' errors is that they do not even know they have made a mistake, and they are likely to repeat the same mistake(s) feeling that what they produce is correct. The teacher did not correct or respond to a student when she rendered cybertheft as هاككردن [hacking], in the example below. This is a non-binary error because, albeit the two concepts are not quite the same, they have the common semantic relation of being a crime committed electronically.

\section{Example 10:}

ST: Cybertheft: the act of using an online service... to steal someone else's property...

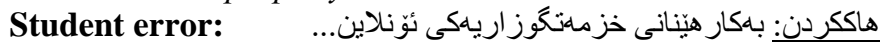

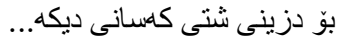

Back translation: [Hacking: the act of using an online service... to steal someone else's property...]

A more serious error that was ignored by the teacher occurred in the example below, in which a student erroneously translated as a downfall in the global economy. This is a binary error because there is no common semantic relationship between the two terms داكثان [incline] and downfall.

\section{Example 11:}

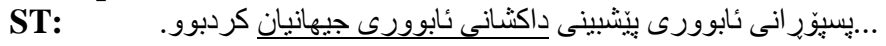
Student error: ...economic experts have predicted a downfall in the global economy.

\section{Focus of Correction/Responding}

In the majority of cases (37 occurrences out of 51), the teachers focused on meaning when responding to errors. There are six cases where the teachers focused on form. There are also eight cases that are ignored by the teachers. As far as the meaning is concerned, the teachers rejected 22 errors and accepted 15 ones, but also offered correction or improvement one way or another. Binary errors are by and large the ones that teachers rejected, and either corrected them themselves or got students to correct them. On the other hand, non-binary errors are by and large the ones that the teachers accepted and offered correction only to improve on the translation.

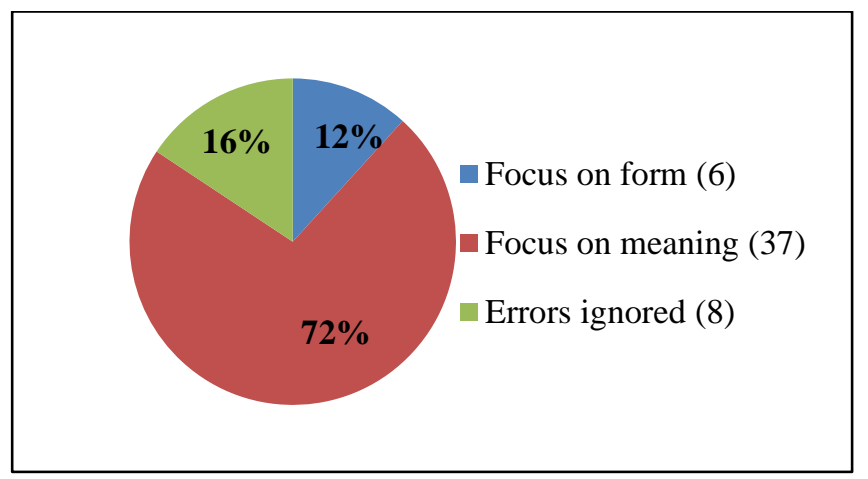

Fig. 2. Focus of teacher's respond to errors

(1) Focus on form: this refers to grammatical and structural aspects of language, which cannot be ignored in language learning as well as translation training classes. "It is now fully accepted that an appropriate amount of class time should be devoted to grammar" (Thompson 1996: 10). Overall, there are six cases in the data (16\%), where the teacher focused on form. In the following example, a student translated the utterance appropriately but made an error in grammar. The teacher detected the error and responded by mirroring back with correct grammar.

\section{Example 12:}

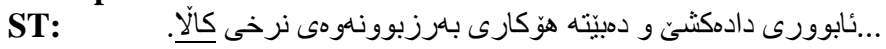
Student error: ...the economy will decline which results in a rise in the price of product.

Teacher correction: ... the economy will decline which results in a rise in the price of products.

On another occasion, the teacher responded to a grammatical mistake (the example below) by mirroring back with correction. The teacher also explained that the word كرنگ is an adjective that should be replaced by the adjective form - significant.

\section{Example 13:}

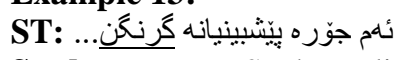

Student error: Such predictions are significance...

Teacher correction: Such predictions are significant...

(2) Focus on meaning: this refers to the semantic aspect of the utterance as opposite to its formal structure. In the data, the teachers largely focused on meaning in their responses to errors ( $72 \%$ of all occurrences). Most of the examples discussed above are instances of meaning-based error responding. To further 
explain the point, consider the example below, which is an instance of non-binary error.

\section{Example 14:}

ST: The claimant must let the court know before the eviction is due to take place.

Student error:

Teacher correction:

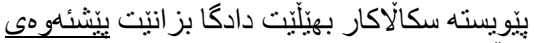

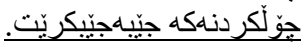

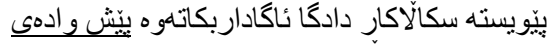

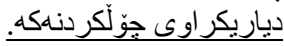

The instance occurs in a legal document. As can be seen, the translation is not a serious error and the teacher accepted it. However, feeling that the reference of time is a key element in the legal document and is missing in the translation, the teacher highlighted the point and suggested an alternative translation that explicitly states the time reference.

\section{CONCLUSION}

It is worth praising that the teachers did not interrupt students in mid-sentence, but allowed them to finish what they wanted to share. The teachers have used an array of error responding techniques, including students' involvement and offering their own corrections (with or without feedback). It can be claimed that the teachers have been successful in as much as they have not interrupted students straightway and they have responded to the vast majority of translation errors $(84 \%)$ occurred in the chosen online classes. Moreover, teachers' offering of valuable feedback in nearly one-fourth of occurrences has also contributed to the effectiveness of the errors responding process in the online classes.

Nevertheless, the large number of instances (one-third of occurrences) that the teachers responded by offering correction without feedback can be rightly criticized. Moreover, ignoring a considerable number of meaning-related errors (16\%) will not lead to a desired outcome as students do not realize they have made a mistake in the first place, let alone correct it.

Finally, it can be concluded that students' errors can be responded to in online translation classes as effectively as traditional classes, provided the teacher chooses the right time to respond and the right technique(s) of responding. It is crucial for any would-be translation teachers and trainers not to interrupt students in mid-sentence. First and foremost, teachers are expected to get individual students to correct their errors, because students learn more effectively when they correct their errors themselves. If this does not work, teachers can ask other students to correct errors made by individual students, provided that the teacher has already established a sense of cooperation in the class. As a last resort, teachers can provide their own corrections only when students struggle to come up with a correct answer.
APPENDIX 1

\section{Student Translation Errors and Teacher's Corrections}

\begin{tabular}{|c|c|c|c|c|}
\hline \multicolumn{5}{|c|}{ Findings in Lesson 1} \\
\hline & No. & ST (English) & $\begin{array}{l}\text { TT with error } \\
\text { (Kurdish) }\end{array}$ & $\begin{array}{l}\text { Teacher } \\
\text { response/ } \\
\text { correction }\end{array}$ \\
\hline \multirow{7}{*}{ 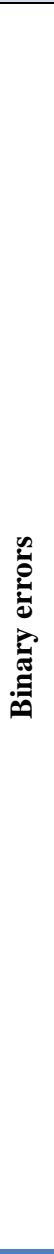 } & 1 & $\begin{array}{l}\text { If you can pay off } \\
\text { any arrears, } \\
\text { contact the } \\
\text { claimant... } \\
\text { immediately you } \\
\text { get this [eviction] } \\
\text { notice. }\end{array}$ & 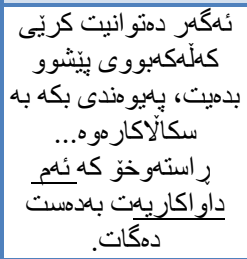 & 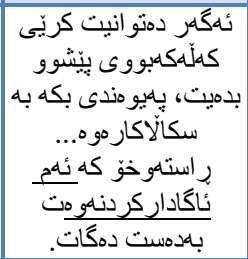 \\
\hline & 2 & $\begin{array}{c}\text { Make sure that } \\
\text { you get a receipt } \\
\text { for any payments } \\
\text { you make. }\end{array}$ & 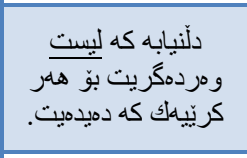 & 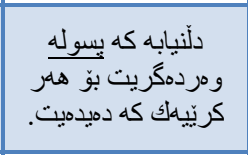 \\
\hline & 3 & $\begin{array}{l}\text {...the claimant } \\
\text { must let the court } \\
\text { know before the } \\
\text { eviction is due to } \\
\text { take place. }\end{array}$ & 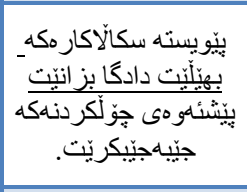 & 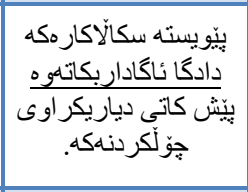 \\
\hline & 4 & $\begin{array}{c}\text { Spousal Abuse: } \\
\text { physical, sexual, } \\
\text { or psychological } \\
\text { violence... }\end{array}$ & 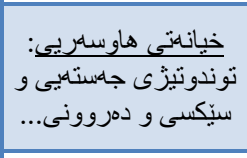 & توندونديزئزى جامستهيى هاوسيى: \\
\hline & 5 & $\begin{array}{l}\text {...he was trying to } \\
\text { get custody of } \\
\text { their child. }\end{array}$ & 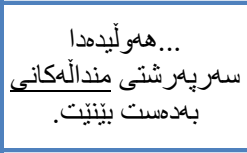 & 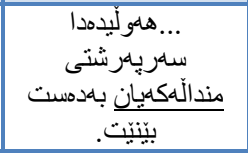 \\
\hline & 6 & $\begin{array}{c}\text { Contact } \\
\text { Monday to Friday } \\
\text { between the hours } \\
\text { of 09:00am - } \\
\underline{10: 15 \mathrm{am}} \\
\end{array}$ & 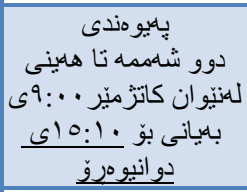 & 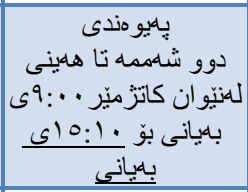 \\
\hline & 7 & $\begin{array}{l}\text { Cybertheft: the act } \\
\text { of using an online } \\
\text { service... to steal } \\
\text { someone else's } \\
\text { property... }\end{array}$ & 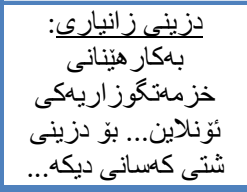 & 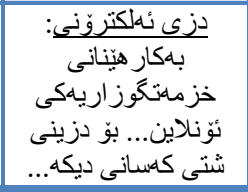 \\
\hline \multirow{6}{*}{ 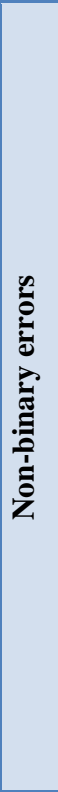 } & 8 & $\begin{array}{l}\text {...the claimant } \\
\text { must let the court } \\
\text { know before the } \\
\text { eviction is due to } \\
\text { take place. }\end{array}$ & 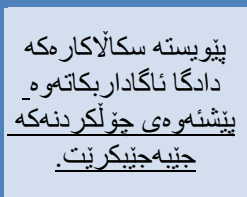 & 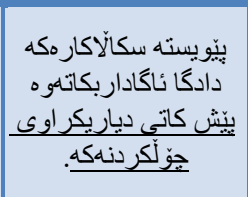 \\
\hline & 9 & $\begin{array}{l}\text { get custody of } \\
\text { their child. }\end{array}$ & 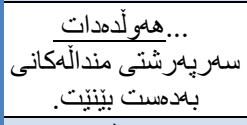 & Ignore \\
\hline & 10 & $\begin{array}{c}\text { Cybercrime: } \\
\text { Crimes committed } \\
\text { electronically... }\end{array}$ & 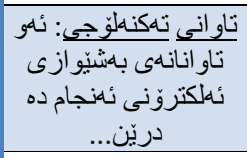 & 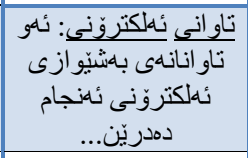 \\
\hline & 11 & $\begin{array}{c}\text { Cybercrime: } \\
\text { Crimes committed } \\
\text { electronically... }\end{array}$ & 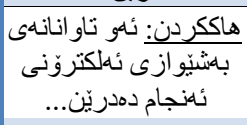 & Ignore \\
\hline & 12 & $\begin{array}{c}\text { A lawsuit or } \\
\text { action in a court... }\end{array}$ & 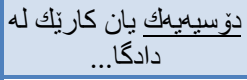 & 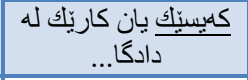 \\
\hline & 13 & $\begin{array}{c}\text {... whose } \\
\text { telephone number } \\
\text { (政 available) is } \\
01484221000\end{array}$ & 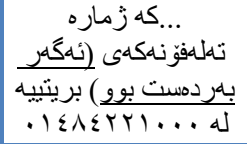 & 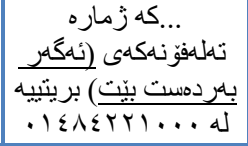 \\
\hline
\end{tabular}




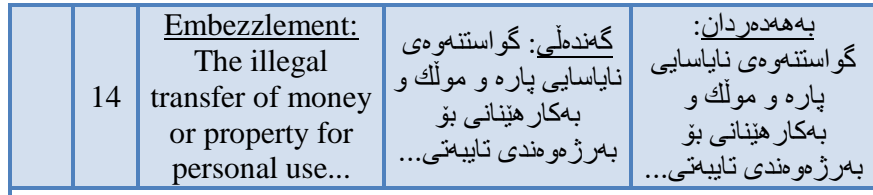

Findings in Lesson 2

\begin{tabular}{|c|c|c|c|c|}
\hline & No. & ST (Kurdish) & $\begin{array}{l}\text { TT with error } \\
\text { (English) }\end{array}$ & $\begin{array}{l}\text { Teacher } \\
\text { response/ } \\
\text { correction }\end{array}$ \\
\hline \multirow{11}{*}{ 递 } & 1 & 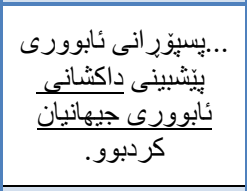 & 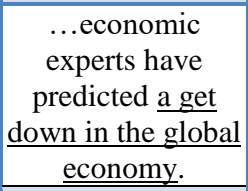 & $\begin{array}{c}\text {...economic } \\
\text { experts have } \\
\text { predicted a decline } \\
\text { in the global } \\
\text { economy. }\end{array}$ \\
\hline & 2 & 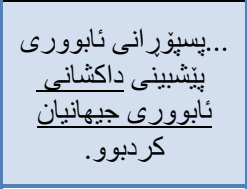 & $\begin{array}{c}\text {...economic } \\
\text { experts have } \\
\text { predicted a } \\
\text { downfall in the } \\
\text { global economy. }\end{array}$ & Ignored \\
\hline & 3 & 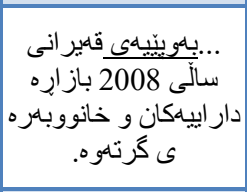 & $\begin{array}{l}\text {... accordingly the } \\
2008 \text { crisis } \\
\text { affected financial } \\
\text { markets and real } \\
\text { estate. }\end{array}$ & $\begin{array}{l}\text {... because the } \\
2008 \text { crisis } \\
\text { affected financial } \\
\text { markets and real } \\
\text { estate. }\end{array}$ \\
\hline & 4 & 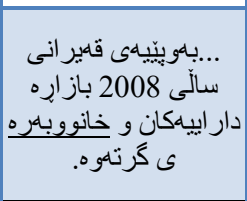 & $\begin{array}{c}\text {...because the } \\
2008 \text { crisis } \\
\text { affected financial } \\
\text { markets and } \\
\text { estate. }\end{array}$ & $\begin{array}{c}\text {...because the } \\
2008 \text { crisis } \\
\text { affected financial } \\
\text { markets and real } \\
\text { estate. }\end{array}$ \\
\hline & 5 & كوّى كَثنى باهر هلمى جيهان & $\frac{\text { General Global }}{\text { Sum }}$ & Ignored \\
\hline & 6 & 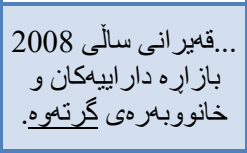 & $\begin{array}{l}\text {...the } \overline{2008} \text { crisis } \\
\text { concluded } \\
\text { financial markets } \\
\text { and real estate. }\end{array}$ & $\begin{array}{c}\text {...the } 2008 \text { crisis } \\
\text { included financial } \\
\text { markets and real } \\
\text { estate. }\end{array}$ \\
\hline & 7 & 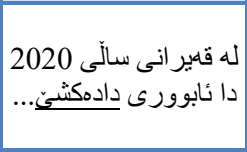 & $\begin{array}{c}\text { The } 2020 \text { crisis } \\
\text { will result in an } \\
\text { economic } \\
\text { inflation... }\end{array}$ & $\begin{array}{l}\text { The } 2020 \text { crisis } \\
\text { will result in an } \\
\text { economic } \\
\text { incline... }\end{array}$ \\
\hline & 8 & 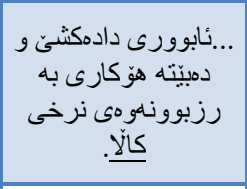 & $\begin{array}{l}\text {...the economy } \\
\text { will decline which } \\
\text { results in a rise in } \\
\text { the price of } \\
\text { facilities. }\end{array}$ & $\begin{array}{l}\text {...the economy } \\
\text { will decline which } \\
\text { results in a rise in } \\
\text { the price of goods. }\end{array}$ \\
\hline & 9 & 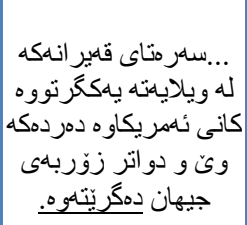 & $\begin{array}{l}\text {...the crisis will } \\
\text { first appear in the } \\
\text { US including most } \\
\text { of the world. }\end{array}$ & $\begin{array}{l}\text {...the crisis will } \\
\text { first appear in the } \\
\text { US and then } \\
\text { covers most of the } \\
\text { world. }\end{array}$ \\
\hline & 10 & 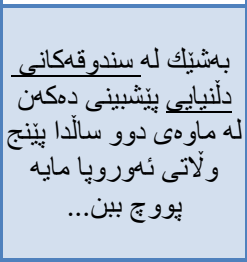 & $\begin{array}{c}\text { Some } \\
\text { confirmations } \\
\text { predict that five } \\
\text { European } \\
\text { countries will go } \\
\text { bankrupt within } \\
\text { two years... }\end{array}$ & $\begin{array}{l}\text { Some insurance } \\
\underline{\text { funds predict that }} \\
\text { five European } \\
\text { countries will go } \\
\text { bankrupt within } \\
\text { two years... }\end{array}$ \\
\hline & 11 & 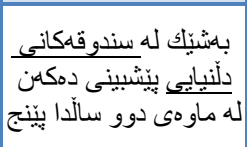 & $\begin{array}{l}\text { Some security } \\
\text { funds predict that } \\
\text { five European } \\
\text { countries will go }\end{array}$ & $\begin{array}{l}\text { Some insurance } \\
\text { funds predict that } \\
\text { five European } \\
\text { countries will go }\end{array}$ \\
\hline
\end{tabular}

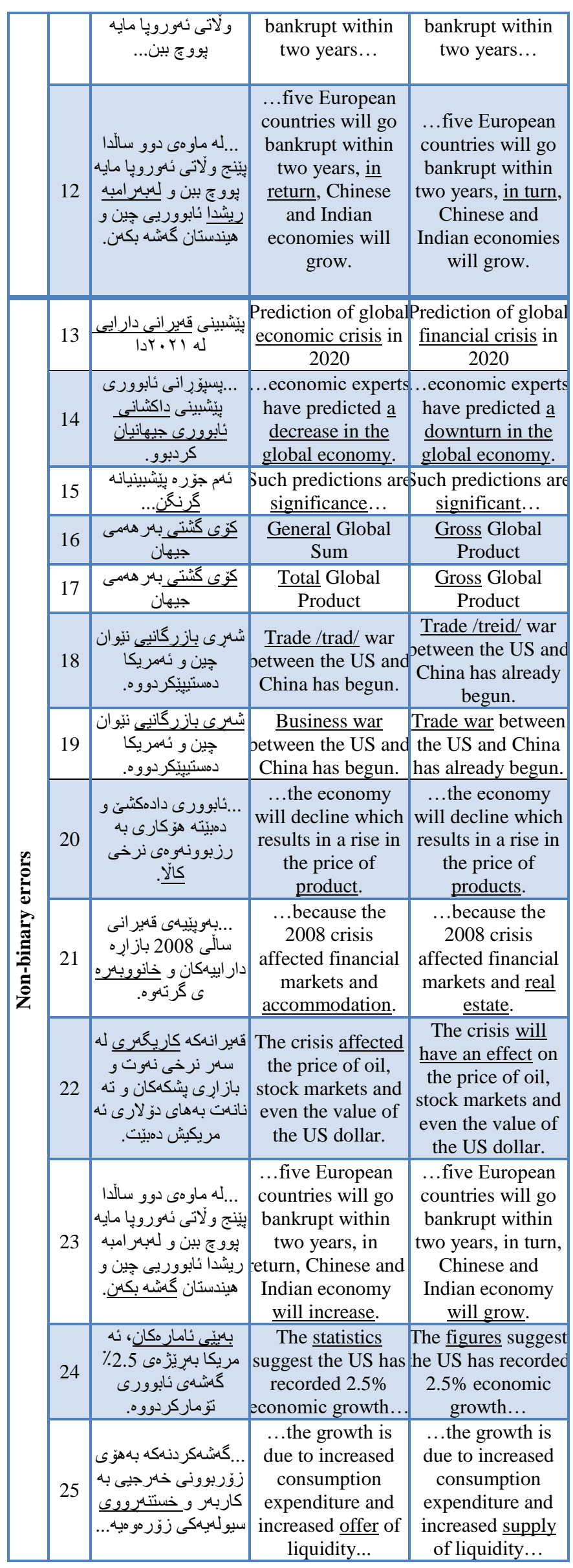




\begin{tabular}{|c|c|c|c|c|}
\hline \multicolumn{5}{|c|}{ Findings in Lesson 3} \\
\hline & No. & ST (English) & $\begin{array}{l}\text { TT with error } \\
\text { (Kurdish) }\end{array}$ & $\begin{array}{l}\text { Teacher } \\
\text { response/ } \\
\text { correction }\end{array}$ \\
\hline \multirow{9}{*}{ 党 } & 1 & $\begin{array}{l}\text { With time, and the } \\
\text { help of friends, he } \\
\text { decided that his } \\
\text { only chance to } \\
\text { make his life work } \\
\text { was to let go of } \\
\text { the anger... }\end{array}$ & 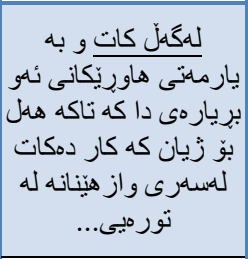 & 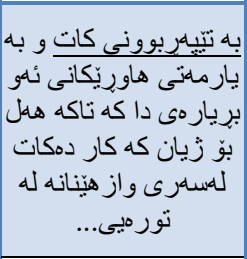 \\
\hline & 2 & $\begin{array}{l}\text { With time, and the } \\
\text { help of friends, he } \\
\text { decided that his } \\
\text { only chance to } \\
\text { make his life work } \\
\text { was to let go of the } \\
\text { anger... }\end{array}$ & 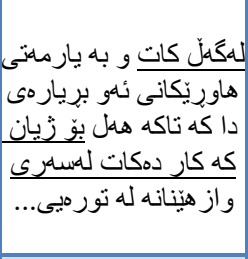 & Ignored \\
\hline & 3 & $\begin{array}{l}\text { With time, and the } \\
\text { help of friends, he } \\
\text { decided that his } \\
\text { only chance to } \\
\text { make his life work } \\
\begin{array}{c}\text { was to let go of } \\
\text { the anger... }\end{array}\end{array}$ & 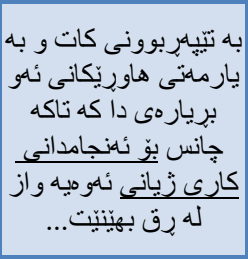 & Ignored \\
\hline & 4 & $\begin{array}{l}\text {...to let go of the } \\
\text { anger, and } \\
\text { somehow forgive } \\
\text { the offender. }\end{array}$ & 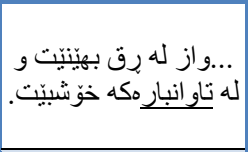 & Ignored \\
\hline & 5 & $\begin{array}{l}\text { The first group } \\
\text { remains prisoners } \\
\text { of their own anger } \\
\text { and bitterness. }\end{array}$ & 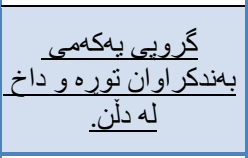 & 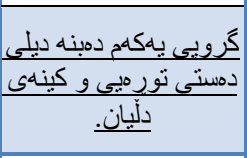 \\
\hline & 6 & $\begin{array}{l}\text { After any major } \\
\text { loss, there is } \\
\text { always a } \\
\text { mourning process. }\end{array}$ & 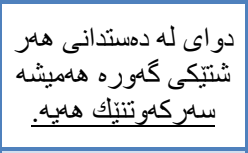 & 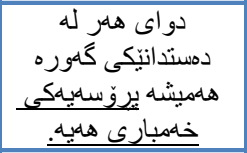 \\
\hline & 7 & $\begin{array}{l}\text { After any major } \\
\text { loss, there is } \\
\text { always a } \\
\text { mourning process. }\end{array}$ & 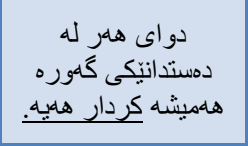 & 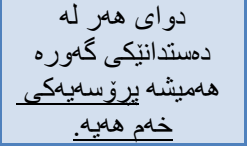 \\
\hline & 8 & $\begin{array}{c}\text { But ultimately, the } \\
\text { question is } \\
\text { whether the } \\
\text { experience makes } \\
\frac{\text { you harder or }}{\text { softer. }}\end{array}$ & 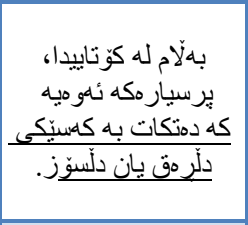 & 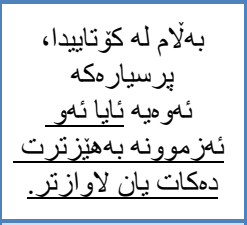 \\
\hline & 9 & $\begin{array}{l}\text { But ultimately, the } \\
\text { question is } \\
\text { whether the } \\
\text { experience makes } \\
\begin{array}{c}\text { you harder or } \\
\text { softer. }\end{array}\end{array}$ & 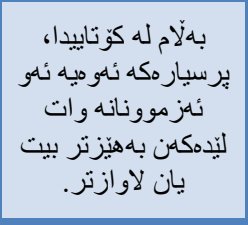 & 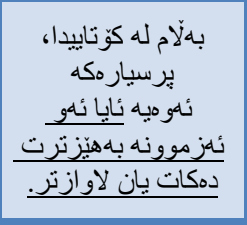 \\
\hline \multirow{4}{*}{ 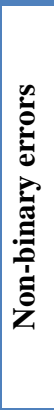 } & 10 & $\begin{array}{l}\text {...to let go of the } \\
\text { anger, and } \\
\text { somehow forgive } \\
\text { the offender. }\end{array}$ & 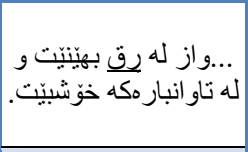 & Ignored \\
\hline & 11 & $\begin{array}{l}\text { After any major } \\
\underline{\text { loss}}, \text { there is } \\
\text { always a } \\
\text { mourning process. }\end{array}$ & 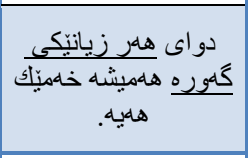 & 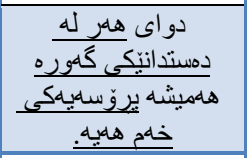 \\
\hline & 12 & $\begin{array}{l}\text { The tragedy saw } \\
\text { Sandy descend }\end{array}$ & 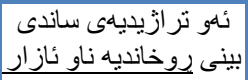 & 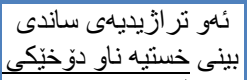 \\
\hline & & into a personal & و رقفهوه. & ير لهي ئاز ار تورهيى. \\
\hline
\end{tabular}

\begin{tabular}{|l|l|c|l|l|}
\hline & & $\frac{\text { hell of pain and }}{\text { anger. }}$ & & \\
\hline
\end{tabular}

\section{APPENDIX 2}

Online Class Observation: Responding to Errors (Lesson 1)

Title of lesson 1: Practical Legal Translation (English into Kurdish)

Main aim(s) of lesson: (1) to train students on translating legal texts, specifically focusing on legal terminology; and (2) to introduce students to a set of common English legal and criminological terms along with their Kurdish translation.

\section{Types of correction}

Put a tick $(\checkmark)$ in the relevant boxes below every time you hear the teacher use the following correction techniques.

\begin{tabular}{|c|c|c|c|}
\hline \multicolumn{2}{|r|}{ Type } & Occurrence & Total \\
\hline \multirow{3}{*}{$\sum_{z}^{z}$} & Interrupt student & $\mathbf{0}$ & $\mathbf{0}$ \\
\hline & $\begin{array}{l}\text { Delay to end of student utterance } \\
\text { (end of translation unit) }\end{array}$ & $\begin{array}{l}\checkmark \checkmark \checkmark \checkmark \checkmark \checkmark \checkmark \\
\checkmark \checkmark \checkmark \checkmark \checkmark \checkmark \checkmark\end{array}$ & 14 \\
\hline & Delay to end of activity & $\mathbf{0}$ & $\mathbf{0}$ \\
\hline \multirow{6}{*}{$\underset{2}{2}$} & Mirror with correction & $\mathbf{0}$ & $\mathbf{0}$ \\
\hline & Get student to correct & $\checkmark$ & 1 \\
\hline & $\begin{array}{l}\text { Asking other student(s) to } \\
\text { correct }\end{array}$ & $\checkmark$ & 1 \\
\hline & Offer correction with feedback & $\checkmark \checkmark \checkmark \checkmark \checkmark$ & 5 \\
\hline & $\begin{array}{l}\text { Offer correction without } \\
\text { feedback }\end{array}$ & $\checkmark \checkmark \checkmark \checkmark \checkmark$ & 5 \\
\hline & Ignore & $\sqrt{ }$ & 2 \\
\hline
\end{tabular}

\section{Focus of correction/responding}

Note down the kind of response that the teacher gives to any student errors as to whether the teacher focuses

on form or meaning (you may need to mark more than one box for a response).

\begin{tabular}{|c|c|c|c|}
\hline \multicolumn{2}{|r|}{ Type } & Occurrence & Total \\
\hline \multirow{2}{*}{ 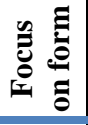 } & Correct overtly & $\checkmark \checkmark$ & 2 \\
\hline & Correct covertly & $\mathbf{0}$ & $\mathbf{0}$ \\
\hline \multirow{2}{*}{ 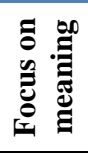 } & $\begin{array}{l}\text { Reject meaning } \\
\text { (binary errors) }\end{array}$ & $\checkmark \checkmark \checkmark \checkmark \checkmark \checkmark$ & 6 \\
\hline & $\begin{array}{c}\text { Accept meaning } \\
\text { (non-binary errors) }\end{array}$ & $\checkmark \checkmark \checkmark \checkmark$ & 4 \\
\hline \multicolumn{2}{|r|}{ Ignore } & $\sqrt{ }$ & 2 \\
\hline
\end{tabular}

\section{APPENDIX 3}

Online Class Observation: Responding to Errors (Lesson 2)

Title of lesson 2: Practical Translation of Economic Texts (Kurdish into English)

Main aim(s) of lesson: to train students on translating economics texts, specifically focusing on economic terminology. 


\section{Types of correction}

Put a tick $(\checkmark)$ in the relevant boxes below every time you hear the teacher use the following correction techniques.

\begin{tabular}{|c|c|c|c|}
\hline \multicolumn{2}{|r|}{ Type } & Occurrence & Total \\
\hline \multirow{3}{*}{$\sum^{2}$} & Interrupt student & $\mathbf{0}$ & $\mathbf{0}$ \\
\hline & $\begin{array}{l}\text { Delay to end of student } \\
\text { utterance (end of } \\
\text { translation unit) }\end{array}$ & $\begin{array}{l}\checkmark \checkmark \checkmark \checkmark \checkmark \checkmark \\
\sqrt{ } \checkmark \sqrt{ } \\
\checkmark \checkmark \checkmark \\
\checkmark \checkmark \checkmark \checkmark \checkmark \\
\end{array}$ & 25 \\
\hline & Delay to end of activity & $\mathbf{0}$ & $\mathbf{0}$ \\
\hline \multirow{6}{*}{$\stackrel{3}{\underline{z}}$} & Mirror with correction & $\checkmark \checkmark$ & 2 \\
\hline & Get student to correct & $\checkmark$ & 1 \\
\hline & $\begin{array}{l}\text { Asking other student(s) to } \\
\text { correct }\end{array}$ & $\checkmark \checkmark \checkmark \checkmark \checkmark$ & 5 \\
\hline & $\begin{array}{c}\text { Offer correction with } \\
\text { feedback }\end{array}$ & $\checkmark \checkmark \checkmark \checkmark \checkmark$ & 5 \\
\hline & $\begin{array}{l}\text { Offer correction without } \\
\text { feedback }\end{array}$ & $\begin{array}{l}\checkmark \checkmark \checkmark \checkmark \checkmark \\
\checkmark \checkmark \checkmark \checkmark \checkmark \\
\end{array}$ & 10 \\
\hline & Ignore & $\checkmark \checkmark$ & 2 \\
\hline
\end{tabular}

\section{Focus of correction/responding}

Note down the kind of response that the teacher gives to any student errors as to whether the teacher focuses on form or meaning (you may need to mark more than one box for a response).

\begin{tabular}{|c|c|c|c|}
\hline \multicolumn{2}{|r|}{ Type } & Occurrence & Total \\
\hline \multirow{2}{*}{ 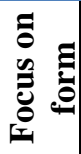 } & Correct overtly & $\checkmark \checkmark \checkmark$ & 3 \\
\hline & $\begin{array}{l}\text { Correct covertly } \\
\text { (mirroring back) }\end{array}$ & $\checkmark$ & 1 \\
\hline \multirow{2}{*}{ 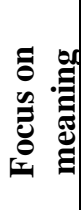 } & $\begin{array}{c}\text { Reject meaning } \\
\text { (binary errors) }\end{array}$ & $\begin{array}{l}\checkmark \checkmark \checkmark \checkmark \checkmark \\
\checkmark \checkmark \checkmark \checkmark \checkmark \\
\end{array}$ & 10 \\
\hline & $\begin{array}{l}\text { Accept meaning } \\
\text { (non-binary errors) }\end{array}$ & $\begin{array}{l}\checkmark \checkmark \checkmark \checkmark \checkmark \\
\checkmark \checkmark \checkmark \checkmark\end{array}$ & 9 \\
\hline & Ignore & $\sqrt{ }$ & 2 \\
\hline
\end{tabular}

\section{APPENDIX 4}

Online Class Observation: Responding to Errors (Lesson 3)

Title of lesson 3: Practical Translation of a General Text (English into Kurdish)

Main aim(s) of lesson: to train students on translating general texts to produce a natural-sounding translation.

\section{Types of correction}

Put a tick $(\checkmark)$ in the relevant boxes below every time you hear the teacher use the following correction techniques.

\begin{tabular}{|c|c|c|c|}
\hline \multicolumn{2}{|c|}{ Type } & Occurrence & Total \\
\hline \multirow{4}{*}{$\begin{array}{c}\text { Interrupt student } \\
\text { Delay to end of student } \\
\text { utterance (end of translation } \\
\text { unit) }\end{array}$} & $\begin{array}{c}\checkmark \checkmark \checkmark \checkmark \checkmark \checkmark \\
\checkmark \checkmark \checkmark \checkmark \checkmark \checkmark\end{array}$ & $\mathbf{1 2}$ \\
\hline & Delay to end of activity & $\mathbf{0}$ & $\mathbf{0}$ \\
\hline & Mirror with correction & $\mathbf{0}$ & $\mathbf{0}$ \\
\hline & Get student to correct & $\checkmark$ & $\mathbf{1}$ \\
\cline { 2 - 4 } & $\begin{array}{c}\text { Asking other student(s) to } \\
\text { correct }\end{array}$ & $\checkmark \checkmark \checkmark$ & $\mathbf{3}$ \\
\cline { 2 - 4 } & Offer correction with feedback & $\checkmark \checkmark$ & $\mathbf{2}$ \\
\cline { 2 - 4 } & $\begin{array}{c}\text { Offer correction without } \\
\text { feedback }\end{array}$ & $\checkmark \checkmark$ & $\mathbf{2}$ \\
\cline { 2 - 4 } & Ignore & $\checkmark \checkmark \checkmark \checkmark$ & $\mathbf{4}$ \\
\hline
\end{tabular}

\section{Focus of correction/responding}

Note down the kind of response that the teacher gives to any student errors as to whether the teacher focuses

on form or meaning (you may need to mark more than one box for a response).

\begin{tabular}{|c|c|c|c|}
\hline \multicolumn{2}{|r|}{ Type } & Occurrence & Total \\
\hline \multirow{2}{*}{$\begin{array}{l} \\
\vdots \\
0 \\
0 \\
0 \\
0 \\
0\end{array}$} & Correct overtly & $\mathbf{0}$ & $\mathbf{0}$ \\
\hline & Correct covertly & $\mathbf{0}$ & $\mathbf{0}$ \\
\hline \multirow{2}{*}{ 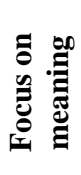 } & $\begin{array}{l}\text { Reject meaning } \\
\text { (binary errors) }\end{array}$ & $\checkmark \checkmark \checkmark \checkmark \checkmark \checkmark$ & 6 \\
\hline & $\begin{array}{c}\text { Accept meaning } \\
\text { (non-binary errors) }\end{array}$ & $\checkmark \checkmark$ & 2 \\
\hline & Ignore & $\checkmark \checkmark \checkmark \checkmark$ & 4 \\
\hline
\end{tabular}

\section{REFERENCES}

Allwright, D., and Bailey, K. M. (1991). Focus on the Language Classroom: An Introduction to Classroom Research for Language Teachers. Cambridge: Cambridge University Press.

Amara, N. (2015). 'Errors Correction in Foreign Language Teaching'. The Online Journal of New Horizons in Education. 5 (3), pp. 58-68.

Baker, M. (2018). In Other Words: A Coursebook on Translation. (3rd ed.) London and New York: Routledge.

Carl, M., and Báez, M. C. T. (2019). 'Machine Translation Errors and the Translation Process: A Study across Different Languages'. Journal of Specialised Translation, (31), pp. 107-132.

Edge, J. (1989). Mistakes and Correction. New York: Longman.

Ghasemi, H. and M., Hasemian (2016). 'A Comparative Study of Google Translate Translations: An Error Analysis of English-to-Persian and Persian-to-English Translations'. English Language Teaching. 9(3), pp. 13-17.

Gouadec, D. (1989). 'Comprendre, évaluer, prévenir. Pratique, ensei- gnement et recherche face à l'erreur et à la faute en

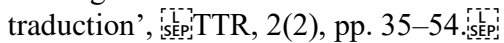

Gower, R., Phillips, D. and Walters, S. (1995). Teaching Practice Handbook. Oxford: Macmillan Heinemann.

Hansen, G. (2010). Translation 'Errors'. In: Gambier, Y., van Doorslaer, L. (eds). Handbook of Translation Studies. Amsterdam: John Benjamins, pp. 385-388. 
Harmer, J. (2001). The Practice of English Language Teaching. Essex: Longman.

Ismail, S., Alsager, H. N., and Omar, A. (2019). 'The Implications of Online Translation Courses on Instructors' Philosophy of Teaching'. Arab World English Journal (AWEJ), Special Issue on CALL (5), pp. 176-189.

Kostić-Bobanović, M. (2007). 'Should Teachers Correct Students' Oral Errors?’ In: Međunarodni znanstveni i stručni skup. Sveučilište Jurja Dobrile u Puli, Odjel za obrazovanje učitelja i odgajatelja, Medulin, pp. 377-385.

Larson, M. L. (1998). Meaning-Based Translation: A Guide to Cross-Language Equivalence. (2nd ed.) Lanham, New York and London: University Press of America.

Lewis, C. C., and Abdul-Hamid, H. (2006). 'Implementing Effective Online Teaching Practices: Voices of Exemplary Faculty'. Innovative Higher Education, 31(2), pp. 83-98.

Newmark, P. (1988). A Textbook of Translation. Hemel Hempstead: Prentice Hall International.

Popovic, M. and H., Ney (2011). 'Towards Automatic Error Analysis of Machine Translation Output'. Computational Linguistics, 37(4), pp. 657-688.

Pym, A. (1992). Translation Error Analysis and the Interface with Language Teaching. In: C. Dollerup and A. Loddegaard, (eds.) The Teaching of Translation. Amsterdam/Philadelphia: John Benjamins, pp. 279-288.

Rasul, S. H. (2016). 'Translation Constraints and Procedures to Overcome them in Rendering Journalistic Texts'. Journal of University of Human Development, 2(3), pp. 402-419.

Rasul, S. H. (2018). 'Translation of Idioms across Languages'. Transletters. International Journal of Translation and Interpreting, 1, pp. 121-141.

Rasul, S. H. (2019). Journalistic Translation: Procedures and Strategies in English-Kurdish Translation of Media Texts. Newcastle: Cambridge Scholars Publishing.

Thompson, G. (1996). 'Some Misconceptions about Communicative Language Teaching'. ELT Journal, 50(1), pp. 9-15.

Thompson, G. (2007). 'Class Observation: Responding to Errors' Form. MA in TESOL, School of English, University of Liverpool.

Thornbury, S. (1999). How to Teach Grammar. London: Longman. Williams, M. (2004). Translation Quality Assessment: An Argumentation-Centred Approach. Ottawa: University of Ottawa Press. 